\title{
Studied on the Bioremediation Effect of Some Selected Microbes on Domestic Sewage Water
}

\author{
P. K. Agrawal \\ Department of Zoology, B.S.A.(P.G.) College, Mathura, U.P., India
}

\begin{abstract}
Bioremediation involves the use of microbes in controlled conditions to degrade various harmful substances in soil and water. In the proposed work, five species of micro-organisms were used to analyse their impact on various physico-chemical parameters of sewage waste water. In the first stage, the actual physicochemical parameters of the collected sample water were recorded (Fresh sample parameters). Following this, the sample water was inoculated with selected micro-organisms (one at a time). The growth of the microbes was observed carefully over a period of 72 hours after inoculation. The physico-chemical parameters were recorded again and were compared with the fresh sample parameters. The results were analysed for any change and on this basis, an impact factor was developed to analyse the extent of remediation effect. The study reveals that Rhodobacter is a very effective microbe in detoxifying organic matter in the sewage water and improving water quality.
\end{abstract}

Key Words: Bioremediation, microbes, sewage waste, toxicity.

\section{Introduction}

Domestic sewage is a big problem in semi urban areas. The sewage water contains a wide variety of dissolved and suspended impurities, such as organic materials and nutrients that tend to rot. The sewage water also gets mixed with domestic waste and contains food and vegetable wastes. Domestic sewage is also very likely to contain disease-causing microbes. The various substances that we use for keeping our houses clean add to water pollution because they contain harmful chemicals. When sewage enters a lake or stream, it causes eutrophication, leading to excessive growth of algae and bacteria. Some of the organisms that do overpopulate from this can be disease-causing microorganisms.

Bioremediation is an effective method to degrade and detoxify various pollutants in the sewage and domestic waste. This approach uses simple micro-organisms that consume and degrade various organic pollutants. Bioremediation is a cost effective and efficient approach to reduce environmental pollution. The main aim of this work has been to investigate the effectiveness of the use of some common microbes in improving the quality of water taken from sewage sources.

\section{Materials and methods}

Water samples were collected, each month in pre sterilized cleaned, dry, polyethylene bottles which have been previously washed with $20 \%$ nitric acid and subsequently with demineralized water. Samples were collected each month from two wide drains, containing heavy load of sewage waste water. The contents from both the sites were mixed together, soon after collection. This mixture was used as the sample for laboratory work. One part of the sample was analysed for physico-chemical parameters in the laboratory using APHA (1989) guidelines. The parameters, which were tested include -sulphides, ammonia, BOD, TSS (Total suspended solids) and TDS (Total dissolved solids). The other part of the sample was used for bio-remedial treatment. Following five important microbes were selected for analysing their impact in improving the quality of water. These are - Rhodobacter sphaeroides, Acinetobacter calcoaceticus, Streptomyces rochei, Bacillus subtilis and Spirulina platensis. Pure cultures of these bacterial species were obtained from the various sources.

A stirred tank type bioreactor was used for analysing bioremediation impact. One litre of sample water was used in the bioreactor and it was added with inoculum and growth media. The inoculum contained one test organism at a time. The growth was allowed for 72 hours. At different intervals i.e., at 24 hours, 48 hours and 72 hours, the change in physico-chemical parameters of the sample water was recorded and compared with the original sample (fresh sample). For each micro-organism, three samples were analysed (one each month) and an average of the three was finally considered.

\section{Results and Discussion}

The effect of bioremediation was expressed in the form of a simple ratio, called "impact factor". It was calculated as below -

Impact factor $=($ Fresh sample average values -96 hour average values $) / 96$ hour average values 
The value more than zero (i.e., positive value) represents a reduction in the amount of concerned parameter i.e., good bio-remediative effect. On the other hand the value less than zero (i.e., negative value) represents an increase in the amount of concerned parameter i.e., poor effect.

The results have been summarized in following table -1 .

Table - 1

(Values in $\mathrm{mg} / \mathrm{L}$ )

\begin{tabular}{|l|l|l|l|l|l|l|}
\hline & & BOD & Sulphides & Ammonia & TSS & TDS \\
\hline Rhodobacter sp. & Fresh Sample value & 16.54 & 30.54 & 52.15 & 954 & 1054 \\
\cline { 2 - 7 } & 72 hr value & 7.25 & 16.26 & 35.12 & 648 & 1182 \\
\cline { 2 - 7 } & Impact factor & 1.3 & 0.9 & 0.5 & 0.5 & -0.1 \\
\hline Acinetobacter sp. & Fresh Sample value & 13.16 & 33.16 & 46.55 & 854 & 1207 \\
\cline { 2 - 7 } & 72 hr value & 14.52 & 30.24 & 41.91 & 795 & 1016 \\
\cline { 2 - 7 } & Impact factor & -0.1 & 0.1 & 0.1 & 0.1 & 0.12 \\
\hline \multirow{5}{*}{ Streptomyces sp. } & Fresh Sample value & 16.17 & 42.17 & 39.79 & 897 & 1021 \\
\cline { 2 - 7 } & 72 hr value & 13.63 & 38.63 & 36.57 & 912 & 1017 \\
\cline { 2 - 7 } & Impact factor & 0.12 & 0.1 & 0.1 & -0.05 & 0.01 \\
\hline \multirow{5}{*}{ Spirulinas sp. } & Fresh Sample value & 14.66 & 41.7 & 48.24 & 989 & 1047 \\
\cline { 2 - 7 } & 72 hr value & 12.72 & 37.72 & 38.51 & 755 & 784 \\
\cline { 2 - 7 } & Impact factor & 0.2 & 0.1 & 0.3 & 0.3 & 0.3 \\
\cline { 2 - 7 } & Fresh Sample value & 17.8 & 34.9 & 52.68 & 866 & 1119 \\
\cline { 2 - 6 } & 72 hr value & 9.65 & 24.65 & 41.53 & 745 & 1005 \\
\cline { 2 - 6 } & Impact factor & 0.8 & 0.4 & 0.3 & 0.2 & 0.1 \\
\hline
\end{tabular}

Rhodobacter sphaeroides is a purple eubacterium with an extensive metabolic repertoire. Rhodobacter exhibited a positve impact factor especially on BOD. The BOD values were significantly decreased from 16.54 to $7.25 \mathrm{mg} / \mathrm{L}$. This clearly indicates a tremendous oxygenic potential of the bacterium (B. B. Nepple et al, 2000). A simultaneous significant fall in the values of sulphides and ammonia was also noted. The fall was due to the accelerated oxidation of sulphides an ammonium ions by the oxygen liberated by the bacterium (S. Kalpan, 2005).

Acinetobacter calcoaceticus are strictly aerobic, non fermentative, gram negative bacilli. Acinetobacter exhibited a negative impact on BOD. This was probably because the bacterium itself consumes the oxygen for its respiratory needs (Desouky et al, 2003). However a slight but significant positive impact was noted on sulphides and ammonia. A marginal improvement in TSS and TDS was also noted.

Streptomyces are gram positive bacteria, which live mainly as saprophytes. Streptomyces exhibited a positive impact on the BOD. The value of BOD was decreased from $38.18 \mathrm{mg} / \mathrm{l}$ to $32.23 \mathrm{mg} / \mathrm{l}$. Phosphates was decreased from $16.17 \mathrm{mg} / \mathrm{l}$ to $13.63 \mathrm{mg} / \mathrm{l}$. This clearly indicates the potential role of this bacterium in bioremediation. A marginal decrease in the value of sulphides (from 42.17 to $38.63 \mathrm{mg} / \mathrm{L}$ ) and ammonia (from 39.79 to $36.57 \mathrm{mg} / \mathrm{L}$ ) was also noted. However, no significant improvement was noted in the values of TSS and TDS. Bacillus subtilis is a bacterium, which live mainly as saprophytes. They are well known for their antibiotic properties. Bacillus exhibited a positive impact on BOD. This indicates that the bacterium has strong oxidizing potential which can degrade the organic matter. This is also evident from a significant reduction in the values of TDS from 1047 to $784 \mathrm{mg} / \mathrm{L}$. The bacterium also exhibited a positive impact on sulphides and ammonia which further suggest the strong oxidizing capacities of the bacterium.

Spirulina platensis is a blue green algae, obligatory photoautotrophic microbe, greatly decreases the BOD of the mixture. It exhibited a positive impact on the sulphides and ammonia, because of its capacity to oxidize sulphides (Chojnacka K. 2007) and ammonia. A positive impact on TSS and TDS was also recorded. Tanya Kruitz et al (1995) emphasized the role of cyanobacteria in degrading various organic pollutants.

\section{Conclusion}

From the above discussion and analysis it can be concluded that the microbes have a natural tendency to degrade complex compounds into simpler ones. However, in situ bioremediation simply augments and accelerates this capacity manifolds. If microbial digesters are used to treat sewage waste water before its disposal, not only we can save our rivers and other natural water bodies from contamination but also can utilize this water for drinking, washing purposes. Out of the selected microbes, the most significant effect was shown by Rhodobacter species. 


\section{Acknowledgement}

The authors are thankful to the U.G.C. for providing financial assistance.

\section{References}

[1]. Al Garni S, Ghanem K M, Bahobail A S (2009). Biosorption characteristics of Aspergillus fumigatus in removal of cadmium from an aqueous solution. African Journal of Biotechnology 8, 4163-4172.

[2]. Amini M, Younesi H (2009). Biosorption of $\mathrm{Cd}$ (II), Ni (II) and $\mathrm{Pb}$ (II) from aqueous solution by dried biomass of Aspergillusniger : Application of response surface methodology to the optimization of process parameters. Clean-Soil, Air, Water 37, 776-786.

[3]. APHA 1989. Standard methods for the examination of water and waste water. $17^{\text {th }}$ Ed. Washington D.C., U.S.A. pp. 10-203.

[4]. B B Nepple, J Kessi, R Bachofen (2000), Chromate reduction by Rhodobacter sphaeroides; Journal of industrial Microbiology and Biotechnology October 2000, Volume 25, Issue 4, pp 198-203.

[5]. Chojnacka K (2007). Bioaccumulation of Cr (III) ions by blue green alga Spirulina sp. Part 1. A comparison with biosorption. American journal of Agricultural and Biological Science 2, 218-223.

[6]. Desouky, Haleem (2003); Acinetobacter : Environmental and biotechnological applications: African journal of Biotechnology. Vol. 2 (4).P.P. 71-74

[7]. Focht, D D (1997). Hurst. C J Kundsen, G R, Mclnernchy, MJ Stetzenback. L D, and Walter M V, Aerobic botransformation of polychlorinated biphenyls, Manual of Environmental Microbiology. ASM press, Washington DC, 811-814.

[8]. S Kalpan, J Eraso and J H Roh. (2005). Interacting regulatory networks in the facultative photosynthetic bacterium, Rhodobacter sphaeroides 2.4.1. Biochemical society Transaction; 33 (1), 51-55.

[9]. Tanya Kruitz and peter Wolk (1995). Use of filamentous cyanobacteria for Biodegradation of organic pollutants ; Applied and Environmental microbiology; Vol.61(1). 234-238.

[10]. Young S D O, T M Schmidt, J A Zahn, E S Boyd 1, A de la Mora and A A Dispirito, (2003), Role of Rhodobacter sp. Strain PS-9, a purple Non- Sulfur Photosynthetic Bacterium isolated from an anaerobic Swine waste lagoon, in odor remediation, Appl. Environ. Microbiol. 2003 (69) pp. 1710-1720. 